\title{
Association of Healthcare and Aesthetic Procedures with Infections Caused by Nontuberculous Mycobacteria, France, 2012-2020
}

Côme Daniau, Emmanuel Lecorche, Faiza Mougari, Hanaa Benmansour, Claude Bernet, Hervé Blanchard, Jérôme Robert, Anne Berger-Carbonne, Emmanuelle Cambau

We describe nontuberculous mycobacteria (NTM) infections during 2012-2020 associated with health care and aesthetic procedures in France. We obtained epidemiologic data from the national early warning response system for healtcare-associated infections and data on NTM isolates from the National Reference Center for Mycobacteria. We compared clinical and environmental isolates by using whole-genome sequencing. The 85 original cases were reported after surgery $(48,56 \%)$, other invasive procedures $(28,33 \%)$ and other procedures $(9,11 \%)$. NTM isolates belonged to rapidly growing $(73,86 \%)$ and slowly growing $(10,12 \%)$ species; in 2 cases, the species was not identified. We performed environmental investigations for $38(45 \%)$ cases; results for $12(32 \%)$ were positive for the same NTM species as for the infection. In 10 cases that had environmental and clinical samples whose genomes were similar, the infection source was probably the water used in the procedures. NTM infections could be preventable by using sterile water in all invasive procedures.

Author affiliations: Santé Publique France, Saint-Maurice, France (C. Daniau, A. Berger-Carbonne); Université de Paris, Paris,

France (E. Lecorche, E. Cambau); Assistance Publique Hôpitaux de Paris, Paris (E. Lecorche, F. Mougari, H. Benmansour, H. Blanchard, J. Robert, E. Cambau); Centre National de Référence des Mycobactéries et de la Résistance des Mycobactéries aux Antituberculeux, Paris (E. Lecorche, F. Mougari, H. Benmansour, J. Robert, E. Cambau); Centre d'Appui pour la Prévention des Infections Associées aux Soins en Provence-Alpes-Côte-d'Azur, Lyon, France (C. Bernet); Centre d'Appui pour la Prévention des Infections Associées aux Soins en Île-de-France, Paris (H. Blanchard); Centre d'Immunologie et des Maladies Infectieuses (CIMI), Sorbonne Université, Paris (J. Robert)

DOI: https://doi.org/10.3201/eid2803.211791
Tontuberculous mycobacteria (NTM) are ubiqui1 tous bacteria found in soil, water, and other environments $(1,2)$. More than 200 NTM species have been described to date. NTM are classified according to their speed of growth in vitro, specifically rapidly growing mycobacteria (such as Mycobacterium chelonae, M. fortuitum complex, and M. abscessus) and slowly growing mycobacteria (such as M. avium complex, M. marinum, and M. kansasii).

NTM infections are usually not transmissible between humans, although outbreaks linked to the same contamination event or from a common water reservoir have been reported. This finding was especially observed for extrapulmonary NTM infections after invasive procedures because of a common source, such as healthcare-associated infections (HAIs) and those related to medical, aesthetic, or cosmetic procedures (3-7). In particular, NTM HAIs were observed after heart surgery: $>100$ cases of endocarditis caused by a single clone of $M$. chimaera were found in water tanks of heater-cooler units used for cardiac bypass (8). In France, previously reported outbreaks of NTM HAI cases have involved M. xenopi in bone and joint infections after orthopedic surgery (9) and $M$. chelonae in skin infections after mesotherapy cosmetic procedures (5) or in hematopoietic stem cell transplantation (10). Endocarditis on bioprosthetic heart valves were also reported to contain $M$. wolinskyi and M. chelonae (11).

HAI reporting has been mandatory in France since 2001, and reports are collected at the French Public Health Agency. In addition, the National Reference Centre for Mycobacteria and Resistance of Mycobacteria to Anti-Tuberculosis Agents (CNRMyRMA) regularly receives NTM isolates, including 
NTM HAI isolates, from human infections for diagnosis and treatment purposes. A previous case series described an initial cross-database evaluation focusing on NTM infections associated with cosmetic procedures during 2001-2010 (12). We describe episodes of extrapulmonary NTM infections associated with surgical, medical, or aesthetic procedures, including cosmetic care, reported in France during 2012-2020, in and outside healthcare facilities (HCFs).

\section{Materials and Methods}

\section{Data Sources}

We used 2 data sources to include reported cases of NTM infections associated with surgical, medical, or aesthetic procedures during January 2012-June 2020. The first data source was the national early warning response system (EWRS) for HAI diagnosed in HCF, using an electronic reporting process implemented in 2012 (e-SIN), and slightly modified in 2017 (13). The second data source was the NTM isolate database of the CNR-MyRMA, which includes microbiological results of clinical isolates, as well as environmental isolates found after epidemiologic investigations. The Regional Support Centre for the Prevention of Healthcare-Associated Infections conducted epidemiologic investigations. We contacted health professionals who reported cases to the national EWRS for HAI and send isolates to CNR-MyRMA to associate isolates with cases. We used this procedure to set up a single database containing epidemiologic and microbiological data.

\section{Case Definition}

We included extrapulmonary NTM infections defined as a person who had clinical symptoms compatible with an NTM infection and $\geq 1$ NTM-positive microbiological sample (cases considered as NTM colonization by physicians were excluded); and specific surgical, medical, or aesthetic procedures, including cosmetic care, potentially at the origin of the NTM infection. Pulmonary NTM infections, even hospital-acquired, were excluded. We usually consolidated epidemiologically related cases into a single report.

\section{Data Collection and Analysis}

We collected the following information from the 2 data sources: 1) the report itself (the HCF or the laboratory which made the report, date of report); 2) data for infection (date of onset of initial symptoms, symptoms, infection type); 3) the context and suspected cause of the infection (procedure at the origin of the infection, date of contamination or invasive procedure, equipment implicated); 4) epidemic context (number of cases, distribution over time); 5) characteristics of case-patients (age, sex, and immune status); 6) investigation characteristics performed after the NTM infection diagnosis (environmental and professional practices investigations, corrective measures implemented); and 7) microbiological results (name of species and subspecies, whole-genome sequencing [WGS] comparison). We performed a descriptive data analysis by using STATA version 14.2 (https:/ / www.stata.com). We analyzed the rate of NTM infection cases over the study period by using a Poisson regression model.

\section{Genomic Comparison}

We performed genotypic analysis by using WGS to compare isolates found in environmental and clinical samples. We extracted DNA by using the DNA Ultraclean Microbial Kit (QIAGEN, https://www. qiagen.com). We prepared DNA libraries by using the Nextera XT Kit (Illumina, https://www. illumina.com) and sequenced them by using the MiSeq System (Illumina) and MiSeq Reagent V2 (2 $\times 150)$ Kits (Illumina). We performed WGS comparison by aligning sequencing reads of the isolates to a reference genome. We analyzed sequencing data by using Bionumerics version 7.6 (Applied Maths, https://www.applied-maths.com). We trimmed reads to exclude base calls with a Phred score $<15$ and then aligned them by using the Trimming and Resequencing analysis options. The single-nucleotide polymorphism (SNP) signature was built by using the Strict filtering (closed SNP set) option, retaining all SNP with a minimum coverage of $5 \times$, at least covered once in both forward and reverse direction and a minimum distance between retained SNP position of 12 bases, removing the nondiscriminatory position. We used the SNP matrix to build a maximum parsimony tree. We defined a cluster in the WGS analysis by isolates sharing $\leq 10$ or fewer SNPs. WGS data are available from the National Center for Biotechnology Information (https://dataview.ncbi. nlm.nih.gov; under BioProject nos. PRJNA597875, PRJNA657124, PRJNA576780, and PRJNA574109).

\section{Results}

For the study period, 71 reports of extrapulmonary NTM infections related to HAI surgical, medical, or aesthetic procedures were included to give a total of 85 original cases, a mean of 10 cases/year for complete years (i.e., 2012-2019) (Figure 1). The regression identified an increasing trend of cases 


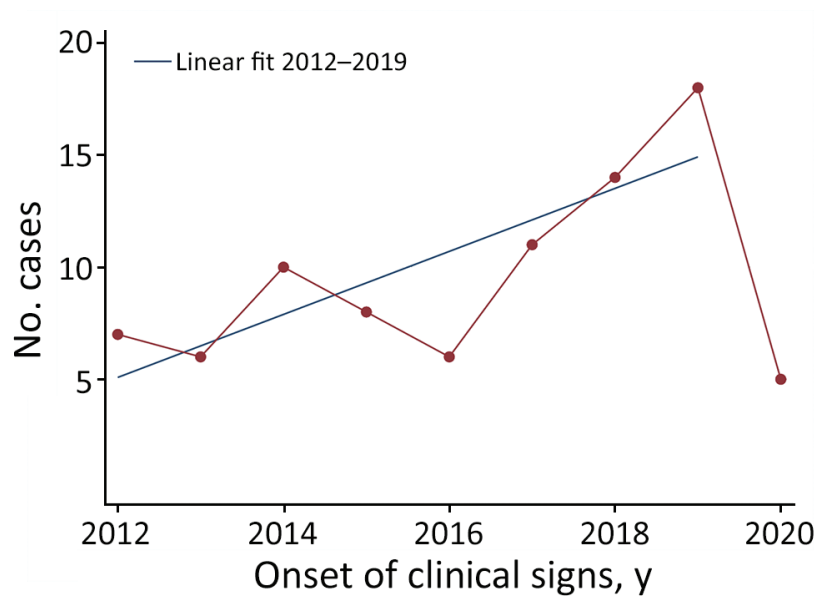

Figure 1. Onset of clinical signs in 85 reported cases of infection with nontuberculous mycobacteria associated with healthcare and aesthetic procedures, by year, France, January 2012-June 2020. Blue line indicates linear fit for 2012-2019 after excluding incomplete year 2020.

per year of onset of clinical signs during the study period after excluding incomplete years $(p<0.01)$. This increase was observed particularly during the period 2016-2019 (i.e., after the M. chimaera heater-cooler unit [HCU] outbreak) but was caused by addition of these cases because regression analysis without them showed a similar significant trend $(\mathrm{p}<0.01)$. Among the 85 cases, $36(42 \%)$ were found in the CNR-MyRMA strain database and the e-SIN database. The CNR-MyRMA database contained 30 additional cases, and the e-SIN database contained 19 additional cases.

The reports were received from $46 \mathrm{HCF}$ s throughout France. Twenty-nine of the HCFs sent only 1 report during the study period, and $16 \mathrm{HCFs}$ sent $>1$ (10 HCFs made 2 reports, 3 HCFs made 3 reports, 2 HCFs made 4 reports, and 1 HCF made 5 reports). Most $(90 \%, 64 / 71)$ of the reports concerned an individual case, and 7 reports concerned clusters ( 2 cases in 4 reports, 3 cases in 1 report, and 5 cases in 2 reports).

For most $(69 \%, 59 / 85)$ of cases, the infection was acquired inside the HCF, whereas 26 cases (31\%) were acquired outside the reporting HCF. These infections acquired outside the HCF were imported either from another HCF $(n=14)$ or from a non-hospital-based medical or aesthetic practice $(n=12)$.

More women than men had cases reported (M:F $=31: 46)$; sex was not reported for 8 case-patients. The median case age was 54 years (range 4-86 years; age was not reported for 12 cases). One third of the cases concerned immunosuppressed patients (33\%, 23/70 cases; 15 cases did not report this information). NTM infections resulted from surgical procedures $(56 \%$,
$48 / 85$ cases), other invasive procedures $(33 \%, 28 / 85$ cases), and noninvasive procedures $(11 \%, 9 / 85$ cases). Cardiovascular surgery $(n=14)$, orthopedic surgery $(n=11)$, plastic surgery (e.g., breast surgery, $(n=13)$, face-lift $(n=2)$, abdominoplasty $(n=1)$, or capillary implant $(n=1)$, and catheter-associated infections $(n=17)$ comprised most of the surgical and other invasive procedure cases reported. The NTM infections concerned mainly skin and soft tissues $(36 \%, 31 / 85)$, intravascular catheters $(20 \%, 17 / 85)$, bones and joints $(18 \%, 15 / 85)$, and arterial/cardiac $(15 \%, 13 / 85)$ (Table 1).

Overall, 14 NTM species were isolated: 10 rapidly growing NTM species and 4 slowly growing NTM species. Rapidly growing NTM were $M$. chelonae $(\mathrm{n}=30), M$. fortuitum complex $(\mathrm{n}=24)$ (17 cases with $M$. fortuitum, 2 with $M$. mageritense, 2 with $M$. porcinum, 1 with $M$. senegalense, and 2 strains for which the exact species could not be determined), M. abscessus $(\mathrm{n}=14), M$. mucogenicum $(\mathrm{n}=5), M$. neoaurum $(\mathrm{n}=2)$, M. fuerthensis $(\mathrm{n}=1)$, and M. wolinskyi $(\mathrm{n}=1)$. Slowly growing NTM species were M. chimaera $(\mathrm{n}=4), M$. avium $(\mathrm{n}=2)$, M. lentiflavum $(\mathrm{n}=1)$, and M. marinum $(\mathrm{n}=1)$. For 2 cases of endocarditis, direct examination of the valve samples identified acid-fast bacilli after Ziehl-Neelsen staining, but culture results were negative.

We determined the hypothesized incubation time (i.e., time between the onset of clinical signs and most probable contamination date, which is most often the date of the procedure) for 50 cases (Table 1). Incubation time was shorter for rapidly growing NTM (median time 34 days, $\mathrm{n}=40$ ) than for slowly growing NTM (median time 549 days, $\mathrm{n}=5$ ).

We suspected that medical devices were related to the infection for $80 \%$ of cases $(68 / 85)$, but a medical device vigilance report was performed for only $21 \%$ of those (14/68 cases). Medical devices comprised implantable devices (e.g., breast prosthesis, artificial heart valve and vascular prosthesis, knee or hip prosthesis) for $50 \%$ of case-patients that had a medical device (34/ 68 cases), invasive devices (e.g., catheter and implantable port, dialysis device, endoscopy device, infiltration device in orthopedic surgery, liposuction cannula, mesotherapy, and tattoo injection equipment) (37\%, 25/68 cases), and noninvasive devices (e.g., cardiopulmonary bypass HCU, contact lens) (13\%, 9/68 cases).

For nearly half of all reported cases $(47 \%, 40 / 85$ cases; 30 cases did not report this information), there was a specific investigation of professional practices after the NTM infection was diagnosed to assess the level of compliance with hygiene guidelines, 
Table 1. Description of 85 reported healthcare and aesthetic-associated NTM infections, France, 2012-2020*

\begin{tabular}{|c|c|c|c|c|c|c|}
\hline Procedure & Infection type & Sex, M/F & $\begin{array}{l}\text { Median } \\
\text { age, y } \\
\text { (range) }\end{array}$ & $\begin{array}{l}\text { Infection risk } \\
\text { factor }\end{array}$ & $\begin{array}{l}\text { Median } \\
\text { incubation } \\
\text { times, d } \\
\text { (range) } \\
\end{array}$ & Species implicated \\
\hline \multicolumn{7}{|l|}{ Surgical, $n=48$} \\
\hline $\begin{array}{l}\text { Cardiovascular } \\
\text { surgery, } n=14\end{array}$ & $\begin{array}{l}\text { Infective } \\
\text { endocarditis } \\
\text { and aortic } \\
\text { infection, } \\
n=13\end{array}$ & $\begin{array}{c}7 / 3 \\
N R=3\end{array}$ & $\begin{array}{c}69(47-81) \\
n=10 \\
N R, n=3\end{array}$ & $\begin{array}{c}\text { None, } n=10 \\
\quad N R, n=3\end{array}$ & $\begin{array}{c}393(14-732) \\
n=11 \\
N R, n=2\end{array}$ & $\begin{array}{c}\text { M. chelonae, } \mathrm{n}=5 ; \\
\text { M. chimaera, } \mathrm{n}=3 ; \text { AFB } \\
\text { positive and culture negative, } \\
\mathrm{n}=2 ; M . \text { wolinskyi, } \mathrm{n}=1 ; \\
M . \text { avium, } \mathrm{n}=1 ; \\
M . \text { abscessus, } \dagger \mathrm{n}=1 ; \\
M . \text { lentiflavum, } \dagger \mathrm{n}=1 ; \\
M . \text { fuerthensis, } \dagger \mathrm{n}=1\end{array}$ \\
\hline & SST, $n=1$ & $0 / 1$ & 69 & None & 41 & M. fortuitum complex, $\mathrm{n}=1$ \\
\hline $\begin{array}{l}\text { Breast surgery, } \\
\mathrm{n}=13\end{array}$ & SST & $1 / 12$ & $\begin{array}{c}42(31-53) \\
n=10 \\
N R, n=3\end{array}$ & $\begin{array}{c}\text { Breast cancer, } \\
\mathrm{n}=2 ; \mathrm{HIV} \\
\mathrm{n}=1 ; \text { none, } \\
\mathrm{n}=8 ; \mathrm{NR}, \mathrm{n}=2\end{array}$ & $\begin{array}{c}36(10-732) \\
n=12 \\
N R, n=1\end{array}$ & $\begin{array}{c}\text { M. fortuitum, } \mathrm{n}=6 ; \\
M . \text { abscessus, } \mathrm{n}=3 \\
\text { M. senegalense, } \mathrm{n}=1 ; \\
\text { M. chelonae, } \mathrm{n}=1 ; \text { M. avium, } \\
\mathrm{n}=1 ; \text { M. chimaera, } \mathrm{n}=1\end{array}$ \\
\hline $\begin{array}{l}\text { Orthopedic surgery, } \\
n=11\end{array}$ & Bone and joint & $\begin{array}{c}5 / 2 \\
N R=4\end{array}$ & $\begin{array}{c}69(45-86) \\
n=7 ; N R \\
n=4\end{array}$ & $\begin{array}{l}\text { None, } \mathrm{n}=6 \\
\quad \mathrm{NR}, \mathrm{n}=5\end{array}$ & $\begin{array}{c}33(23-183) \\
n=9 \\
N R \\
n=2\end{array}$ & $\begin{array}{c}\text { M. fortuitum, } \mathrm{n}=4 \\
\text { M. abscessus, } \mathrm{n}=3 \\
\text { M. mageritense, } \mathrm{n}=2 \\
\text { M. porcinum, } \mathrm{n}=1 \\
\text { M. chelonae, } \mathrm{n}=1\end{array}$ \\
\hline Skin surgery, $\neq n=7$ & SST & $4 / 3$ & $\begin{array}{c}65(42-78) \\
n=6 ; N R \\
n=1\end{array}$ & $\begin{array}{c}\text { None, } n=6 ; \\
n=1\end{array}$ & $\begin{array}{c}45(30-93) \\
n=6, N R \\
n=1\end{array}$ & $\begin{array}{r}M . \text { fortuitum, } \mathrm{n}=3 \\
\text { M. chelonae, } \mathrm{n}=2 \\
\text { M. abscessus, } \mathrm{n}=1 ; \\
M . \text { neoaurum, } \mathrm{n}=1\end{array}$ \\
\hline \multirow[t]{3}{*}{ Other surgery, $\S n=3$} & Vascular, $\mathrm{n}=1$ & NR & NR & NR & NR & M. fortuitum, $\mathrm{n}=1$ \\
\hline & $\begin{array}{l}\text { Urogenital, } \\
\quad n=1\end{array}$ & $0 / 1$ & 48 & None & NR & M. fortuitum, $\mathrm{n}=1$ \\
\hline & Ocular, $n=1$ & $0 / 1$ & 83 & None & 15 & M. chelonae, $\mathrm{n}=1$ \\
\hline \multicolumn{7}{|l|}{ Invasive, $\mathrm{n}=28$} \\
\hline $\begin{array}{l}\text { Vascular catheter } \\
\text { insertion, } \mathrm{n}=17\end{array}$ & $\begin{array}{l}\text { Intravascular } \\
\text { catheter }\end{array}$ & $7 / 10$ & $\begin{array}{l}58(4-82) \\
n=17\end{array}$ & $\begin{array}{c}\text { Chemotherapy, } \\
n=14 ; \text { none, } \\
n=2 ; N R=1\end{array}$ & NR & $\begin{array}{c}\text { M. chelonae, } \mathrm{n}=6 ; \\
\text { M. mucogenicum, } \mathrm{n}=5 ; \\
\text { M. abscessus, } \mathrm{n}=2 ; \\
\text { M. fortuitum, } \mathrm{n}=1 ; M . \text { fortuitum } \\
\text { complex, } \mathrm{n}=1 ; M \text {. porcinum, } \\
\mathrm{n}=1 ; M . \text { neoaurum, } \mathrm{n}=1\end{array}$ \\
\hline Infiltration, $\mathrm{n}=3$ & Bone and joint & $0 / 3$ & $\begin{array}{c}52(52-84) \\
n=3\end{array}$ & $\begin{array}{l}\text { Corticosteroid } \\
\text { infiltration, } n=3\end{array}$ & $\begin{array}{c}61(33-108) \\
n=3\end{array}$ & $\begin{array}{c}\text { M. abscessus, } \mathrm{n}=2 \\
M . \text { chelonae, } \mathrm{n}=1\end{array}$ \\
\hline Mesotherapy, $\mathrm{n}=3$ & SST & $1 / 2$ & $\begin{array}{c}47(35-49) \\
n=3\end{array}$ & None, $\mathrm{n}=3$ & $\begin{array}{c}30(15-73) \\
n=3\end{array}$ & $\begin{array}{l}\text { M. chelonae, } \mathrm{n}=2 \\
\text { M. abscessus, } \mathrm{n}=1\end{array}$ \\
\hline Tattoo, $n=3$ & SST & $3 / 0$ & $\begin{array}{c}50(48-56) \\
n=3\end{array}$ & None, $n=3$ & NR & M. chelonae, $\mathrm{n}=3$ \\
\hline $\begin{array}{l}\text { Intestinal endoscopy, } \\
n=2\end{array}$ & Abdominal & $0 / 2$ & $\begin{array}{c}68(60-75) \\
n=2\end{array}$ & $\begin{array}{c}\text { Kidney } \\
\text { transplant, } \\
\mathrm{n}=1 ; \text { none, } \mathrm{n}=1\end{array}$ & $7(4-10) ; n=2$ & $\begin{array}{l}\text { M. fortuitum, } \mathrm{n}=1 \\
\text { M. abscessus, } \mathrm{n}=1\end{array}$ \\
\hline $\begin{array}{l}\text { Noninvasive, } n=4 \\
\quad \text { Eye lens use, } n=3\end{array}$ & Ocular & $0 / 3$ & $\begin{array}{c}36(21-62) \\
n=3\end{array}$ & None, $n=3$ & NR & M. chelonae, $\mathrm{n}=3$ \\
\hline Balneotherapy, $n=1$ & SST & $0 / 1$ & 51 & $\begin{array}{c}\text { Methotrexate plus } \\
\text { corticosteroids } \\
\text { treatment }\end{array}$ & 20 & M. marinum, $\mathrm{n}=1$ \\
\hline \multirow[t]{4}{*}{ Not identified, $\mathrm{n}=5$} & & & & & & \\
\hline & $\mathrm{SST}, \mathrm{n}=3$ & $1 / 2$ & $\begin{array}{c}44(28-75) \\
n=3\end{array}$ & $\begin{array}{c}\text { Kidney } \\
\text { transplant, } n=1 ; \\
N R=2\end{array}$ & NR & M. chelonae, $\mathrm{n}=3$ \\
\hline & $\begin{array}{l}\text { Disseminated, } \\
\qquad \mathrm{n}=1\end{array}$ & $1 / 0$ & 64 & $\begin{array}{l}\text { Corticosteroids } \\
\text { treatment, } \\
\text { chronic dialysis }\end{array}$ & NR & M. chelonae, $\mathrm{n}=1$ \\
\hline & $\begin{array}{l}\text { Bone and joint, } \\
\qquad \mathrm{n}=1\end{array}$ & $1 / 0$ & 61 & $\begin{array}{c}\text { Corticosteroids } \\
\text { treatment }\end{array}$ & NR & M. chelonae, $\mathrm{n}=1$ \\
\hline
\end{tabular}

${ }^{*}$ AFB, acid-fast bacilli; NR, not reported; NTM, nontuberculous mycobacteria; SST, akin and soft tissue.

†Sample that had several bacteria identified.

‡Skin operations concerning the following diverse procedures: face-lift, $n=2$, abdominoplasty, $n=1$, capillary implant, $n=1$, excision of a basal cell carcinoma, $n=1$, wearing a Holter monitor, $n=1$ and neurostimulation device, $n=1$.

§Lower limb vascular surgery, $n=1$, promontofixation, $n=1$, eye surgery, $n=1$. 
sterilization procedures, and treatment procedures. For more than one fourth of these cases $(28 \%$, $11 / 40$ ), the investigations found failure to comply with infection risk prevention recommendations. Corrective measures were implemented for $45 \%$ of the reports (17/38 reports; 33 did not report this information), most often involving increased hygiene vigilance and recommendations to improve practices $(n=7)$. For 32 reports, there was no active case finding; most of them were isolated cases. For 30 reports, this information was not available. Active case finding was conducted after 9 reports (30 did not report this information) for procedures such as breast reconstruction, heart surgery, gastrointestinal endoscopy, mesotherapy, orthopedic surgery, and tattooing sessions.

Environmental investigations were undertaken for $42 \%(30 / 71)$ of the reports. Most (27/30) reports involved water sampling from potential sources of the contamination, such as water supply networks (n $=21)$, HCU $(n=4)$, dialysis water $(n=1)$, and swimming pool water $(n=1)$. Perioperative surfaces $(n=2)$ and air samples $(n=1)$ were rarely sampled. Among the $45 \%$ of cases $(38 / 85)$ involving environmental investigations, mycobacteria samples were positive for 18 (7 were not reported). The same NTM species as in the clinical isolate was found for 12 cases $(32 \%$, $12 / 38$ ) after environmental investigations. For 10 cases, the clinical isolate could not be distinguished from the environmental isolate (Table 2; Figure 2): $M$. chimaera isolates from HCU and heart surgery infection (patient A3) (Figure 2, panel A), isolates from hospital water supply network, $M$. fortuitum breast infection (patient C1) (Figure 2, panel B), M. chelonae skin and soft tissue infection (patients D1, E1-E2, E3, and F1) (Figure 2, panel C), M. marinum isolates from pool balneotherapy and skin and soft tissue infection (patient I1) (Figure 2, panel D), and M. mucogenicum catheter-associated infection (patients J1, J2, and J3) (Figure 2, panel E).

We also performed genomic comparisons for case-patients suspected of being contaminated by a common source. For 8/10 case-patients, studied isolates had the same pattern (Table 2; Figure 2). In report A, 3 clinical isolates of $M$. chimaera endocarditis from 2 patients were clustered (A1-A2 and A3) (Figure 2, panel A). These 2 patients were linked to a worldwide outbreak of HCU contamination, as shown in the section comparing clinical (A3) and environmental (A4-A8) isolates. In report $\mathrm{H}$, which concerned $M$. chelonae catheter-associated infections diagnosed in the same institution ( $\mathrm{n}=5$ cases), clinical isolates were clustered into 2 distinct groups; the first cluster grouped 3 isolates, H1, H4, and H5, from 3 patients, and the second cluster grouped 2 isolates, $\mathrm{H} 2$ and $\mathrm{H} 3$, from 2 patients (Figure 2, panel C). The presence of 2 clusters in the same HCF suggested that there were 2 sources of contamination, neither of which were found. In report $K$, the same genotype was found when comparing $M$. neoaurum isolates from blood cultures of 1 patient with the isolate found during microbiological control testing after a peripheral autologous stem cell transplant $(\mathrm{n}=$ 1 case) (Figure 2, panel F). The contamination of the stem cell transplant was attributed to colonization of the catheter used for the cell sampling.

\section{Discussion}

We describe extrapulmonary NTM infections diagnosed after surgical, medical, or aesthetic procedures in France over an 8-year period (2012-2020). To broaden the spontaneous reporting from medical professionals, we sought 2 information sources: the national EWRS for HAI and the national reference NTM strain database. Because only 85 cases were described in 71 reports over 8 years, we might consider that such NTM infections remain rare. However, most of the cases were related to a medical device, a specific procedure, or lack of hygiene practices and might have been preventable.

Our study highlights a slight increase in reported annual numbers of cases during the study period. This increase, particularly during 2016 (14), could be explained by greater global awareness in public health community after invasive infections with $M$. chimaera associated with HCUs used during cardiac surgery (15) and other published outbreaks (6).

Both infection sites and NTM species isolated from these cases of infections were diverse, emphasizing the opportunistic nature of these pathogens. The most commonly reported infections were skin and soft tissue infections, catheter-related infections, infective endocarditis, and bone and joint infections. When we compared our findings with the major proportion of extrapulmonary NTM infections described in the literature, but not limited to healthcare-associated and aesthetic procedure-associated infections, we found that skin and soft tissue infections were the most commonly reported infection site $(16,17)$. However, we identified catheter-associated infections, bone and joint infections, or infective endocarditis, which are less described, except for the HCU M. chimaera outbreak (8).

A wide variety of NTM species were responsible for the infections reported in our study; M. chelonae 
and $M$. fortuitum were the most common. Isolates of slowly growing NTM species were rare $(11 \%)$ compared with those found in a review in the United States, in which $50 \%$ of all species were in the $M$. avium complex (16). One possible explanation for this difference is that rapidly growing NTM cultivated on standard bacteriology diagnostic media might constitute an unexpected etiology diagnosis. We should also consider that these rapidly growing species were regularly found in France in the water networks, one of the sources of infection (1).
Most of the cases in our study were linked to surgical, invasive, and noninvasive procedures. In 5 cases, no specific procedures were identified as the cause of infection, even though all patients underwent healthcare procedures such as previous intravenous catheter, or no procedures were identified at all, such as the case of bone and joint infection, which could not have originated from spontaneous infection. As observed in previous reviews, the most commonly reported infections were those associated with aesthetic care (12), particularly breast prostheses (18).

Table 2. Genomic comparison between clinical versus environmental isolates and comparison of clinical isolates for patients suspected of being contaminated with nontuberculous mycobacteria by a common source, France, 2012-2020

\begin{tabular}{|c|c|c|c|c|c|}
\hline Report & Species involved & Case manifestations & $\begin{array}{c}\text { Environmental } \\
\text { sample }\end{array}$ & Result of comparison & $\begin{array}{l}\text { Location of } \\
\text { information* }\end{array}$ \\
\hline$A$ & M. chimaera & $\begin{array}{l}\text { Endocarditis after cardiac } \\
\quad \text { surgery by using } \\
\text { contaminated heater-cooler } \\
\text { unit ( } 2 \text { patients operated on } \\
\text { in } 2 \text { hospitals) }\end{array}$ & $\begin{array}{l}\text { Heater-cooler } \\
\text { unit water }\end{array}$ & $\begin{array}{l}\text { Clinical isolates from the } 2 \\
\text { patients who had } M \text {. chimaera } \\
\text { disseminated disease after } \\
\text { open-heart surgery belonged } \\
\text { to worldwide epidemic cluster. } \\
\text { Environmental isolates, } \\
\text { obtained only for } 1 \text { of the } 2 \\
\text { patients, belonged to } \\
\text { the epidemic cluster for }\end{array}$ & $\begin{array}{l}\text { Figure 2, panel A; } \\
\text { Appendix Table } 1\end{array}$ \\
\hline
\end{tabular}

\begin{tabular}{|c|c|c|c|c|c|}
\hline$B$ & M. chimaera & $\begin{array}{l}\text { Prosthesis infection after } \\
\text { breast reconstruction } \\
\text { (1 patient) }\end{array}$ & $\begin{array}{l}\text { Hospital water } \\
\text { supply network }\end{array}$ & $\begin{array}{l}\text { Environmental and clinical } \\
\text { isolates did not belong to } \\
\text { the same cluster }\end{array}$ & $\begin{array}{l}\text { Figure 2, panel A; } \\
\text { Appendix Table } 1\end{array}$ \\
\hline $\bar{C}$ & M. fortuitum & $\begin{array}{l}\text { Prosthesis infection after } \\
\text { breast reconstruction } \\
\text { (1 patient) }\end{array}$ & $\begin{array}{l}\text { Hospital water } \\
\text { supply network }\end{array}$ & $\begin{array}{l}\text { Environmental and clinical } \\
\text { isolates belonged to the } \\
\text { same cluster }\end{array}$ & $\begin{array}{l}\text { Figure 2, panel B; } \\
\text { Appendix Table } 2\end{array}$ \\
\hline $\bar{D}$ & M. chelonae & $\begin{array}{c}\text { Skin and soft tissue infection } \\
\text { after face lift surgery } \\
\text { (1 patient) }\end{array}$ & $\begin{array}{l}\text { Hospital water } \\
\text { supply network }\end{array}$ & $\begin{array}{l}\text { Environmental and clinical } \\
\text { isolates belonged to the } \\
\text { same cluster }\end{array}$ & $\begin{array}{l}\text { Figure 2, panel C; } \\
\text { Appendix Table } 3\end{array}$ \\
\hline $\bar{E}$ & M. chelonae & $\begin{array}{l}\text { Skin and soft tissue infection } \\
\text { after tattoo ( } 2 \text { patients } \\
\text { tattooed in the same } \\
\text { tattoo parlor) }\end{array}$ & $\begin{array}{l}\text { Tattoo parlor water } \\
\text { supply network }\end{array}$ & $\begin{array}{l}\text { Environmental and clinical } \\
\text { isolates belonged to } \\
\text { the same cluster }\end{array}$ & $\begin{array}{l}\text { Figure 2, panel C; } \\
\text { Appendix Table } 3\end{array}$ \\
\hline$F$ & M. chelonae & $\begin{array}{c}\text { Skin and soft tissue } \\
\text { infection after mesotherapy } \\
\text { ( } 1 \text { patient })\end{array}$ & $\begin{array}{l}\text { Water supply } \\
\text { network from } \\
\text { doctor's office sink } \\
\text { and patient's home }\end{array}$ & $\begin{array}{l}\text { Environmental isolates from } \\
\text { doctor's office sink and clinical } \\
\text { isolate belonged to the same } \\
\text { cluster. Isolates from patient's } \\
\text { home were not related }\end{array}$ & $\begin{array}{l}\text { Figure 2, panel C; } \\
\text { Appendix Table } 3\end{array}$ \\
\hline $\bar{G}$ & M. chelonae & $\begin{array}{l}\text { Skin and soft tissue infection } \\
\text { after mesotherapy } \\
\text { (1 patient) }\end{array}$ & $\begin{array}{l}\text { Water supply } \\
\text { network from } \\
\text { doctor's office sink } \\
\text { and patient's home }\end{array}$ & $\begin{array}{c}\text { Environmental and clinical } \\
\text { isolates did not belong to } \\
\text { the same cluster }\end{array}$ & $\begin{array}{l}\text { Figure 2, panel C; } \\
\text { Appendix Table } 3\end{array}$ \\
\hline$\overline{\mathrm{H}}$ & M. chelonae & $\begin{array}{c}\text { Catheter-associated } \\
\text { infection ( } 5 \text { patients from the } \\
\text { same institution) }\end{array}$ & $\begin{array}{l}\text { No environmental } \\
\text { sample }\end{array}$ & $\begin{array}{l}\text { Two clusters of } 2 \text { clinical } \\
\text { isolates were identified }\end{array}$ & $\begin{array}{l}\text { Figure 2, panel C; } \\
\text { Appendix Table } 3\end{array}$ \\
\hline I & M. marinum & $\begin{array}{l}\text { Skin and soft tissue infection } \\
\text { caused by contamination } \\
\text { after a bath in a } \\
\text { balneotherapy swimming } \\
\text { pool (1 patient) }\end{array}$ & $\begin{array}{l}\text { Swimming pool } \\
\text { water }\end{array}$ & $\begin{array}{l}\text { Environmental and clinical } \\
\text { isolates belong to the } \\
\text { same cluster }\end{array}$ & $\begin{array}{l}\text { Figure 2, panel D; } \\
\text { Appendix Table 4 }\end{array}$ \\
\hline $\mathrm{J}$ & M. mucogenicum & $\begin{array}{c}\text { Catheter-associated } \\
\text { infection ( } 3 \text { patients from the } \\
\text { same institution) }\end{array}$ & $\begin{array}{l}\text { Hospital water } \\
\text { supply network }\end{array}$ & $\begin{array}{l}\text { Environmental and clinical } \\
\text { isolates belong to the } \\
\text { same cluster }\end{array}$ & $\begin{array}{l}\text { Figure 2, panel D; } \\
\text { Appendix Table } 5\end{array}$ \\
\hline$\overline{\mathrm{K}}$ & M. neoaurum & $\begin{array}{l}\text { Catheter-associated } \\
\text { infection discovered during } \\
\text { microbiological control of } \\
\text { autologous stem cell } \\
\text { transplant ( } 1 \text { patient) }\end{array}$ & $\begin{array}{l}\text { Autologous stem } \\
\text { cell transplant; no } \\
\text { environmental } \\
\text { sample }\end{array}$ & $\begin{array}{l}\text { Environmental and clinical } \\
\text { isolates belong to the } \\
\text { same cluster }\end{array}$ & $\begin{array}{l}\text { Figure 2, panel E; } \\
\text { Appendix Table } 6\end{array}$ \\
\hline
\end{tabular}




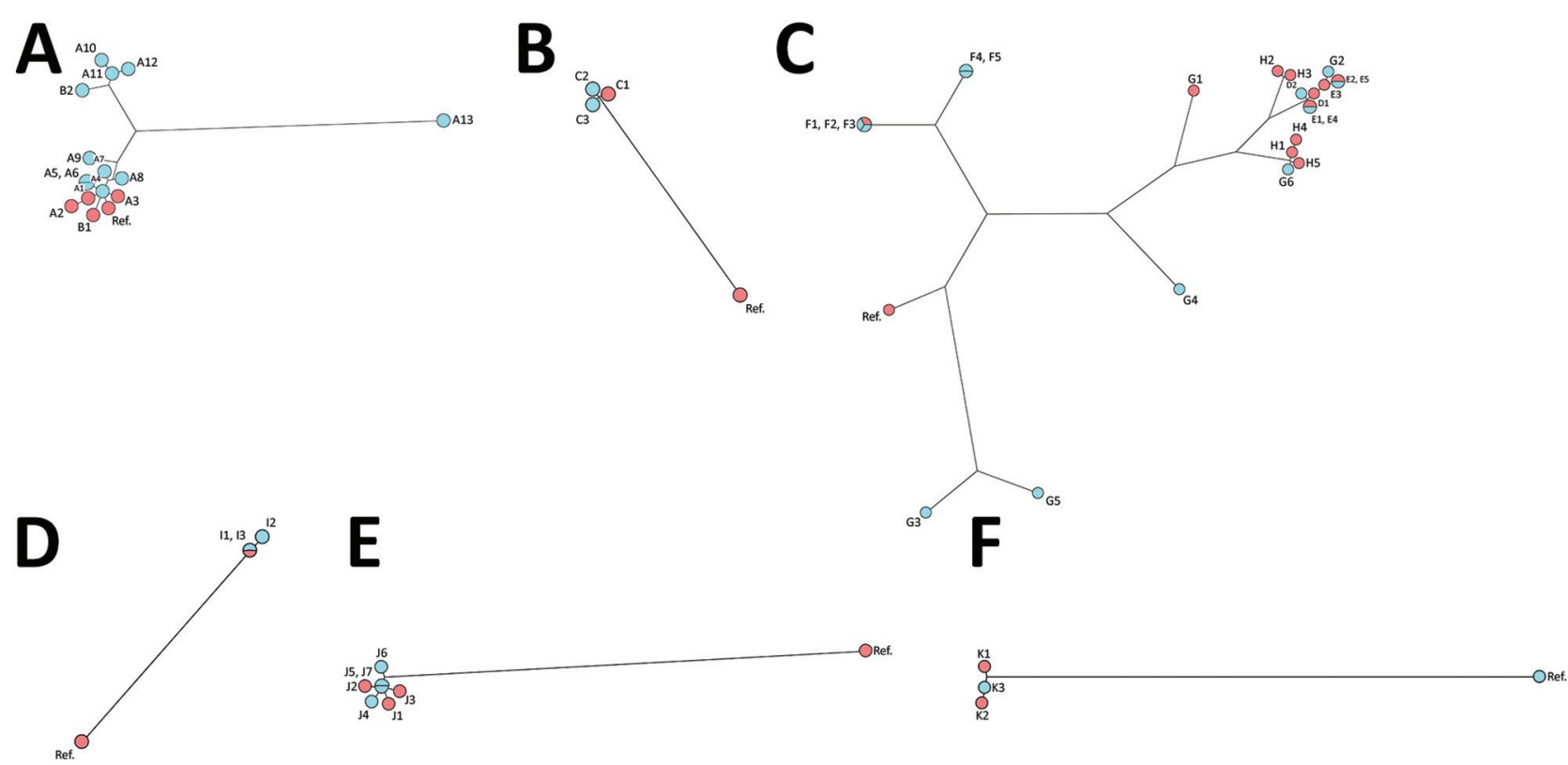

Figure 2. Genomic comparison of nontuberculous mycobacteria isolates by using whole-genome sequencing phylogenetic analysis and maximum parsimony trees. A) Mycobacterium chimaera, B) M. fortuitum, C) M. chelonae, D) M. marinum, E) M. mucogenicum, F) M. neoaurum. Environmental isolates are indicated in blue, and clinical isolates are indicated in red. Additional details on the isolates and their sources are available in an extended figure legend online (https://wwwnc.cdc.gov/EID/article/28/3/21-1791-F2.htm); additional information for the 6 Mycobacterium species tested is provided in the Appendix (https://wwwnc.cdc.gov/EID/article/28/3/21-1791-App1.pdf). Ref, referent.

The source of infection was not determined in 9/10 case-patients, despite environmental investigations conducted for $\approx 50 \%$ of the reports. Even when environmental investigations were performed, they occurred months after the suspected contamination because of long incubation times, as in reports B and $G$ (Table 2).

Because a medical device was implicated in most of the NTM infection cases we reported, we believe that these infections can be prevented. The medical device could be contaminated by NTM before its use or can lead to contamination from environmental $\operatorname{NTM}(5,19)$. When an environmental cause is identified, the water system is the major environmental source most frequently considered responsible. Water systems, particularly in hospitals, are frequently identified as NTM reservoirs $(20,21)$.

Genomic comparison of NTM isolates can be used to rule out or confirm any hypothesis concerning the origin of the contamination. However, careful analysis of genomic sequence comparisons should be conducted because several factors, such as the reference sequence on which the reads are mapped (epidemic strain or unrelated strain), quality of the sequenced data, coverage of the mapping assembly, number of sequences included in the comparison, and use of de novo assembly, influence SNP analysis. WGS appears to be a suitable tool for the molecular investigation of NTM infections, but might need expert rules and standardization to be used further.

The major limitations of this study concern the lack of completeness of the reported data. There is no specific surveillance system for NTM infection in France, and the 2 databases used for this case series are not exhaustive. The purpose of the EWRS for HAI platform is to improve the management of HAI reporting by $\mathrm{HCF}$, and the CNR-MyRMA receives NTM isolates for patient diagnosis and treatment and genotypic comparison in epidemiologically related cases with environmental analyses when necessary. Therefore, underdeclaration of NTM infection cases in France is probable (22). However, when combined, the 2 databases provide a useful inventory of extrapulmonary NTM infection cases related to surgical, medical, and aesthetic procedures. The genomic comparison of NTM isolates performed by CNR-MyRMA was able to demonstrate the source when an environmental investigation was conducted and clinical and environmental isolates were available. This comparison provides valuable pointers for the future implementation, improvement, and follow-up of certain preventive measures.

Although data in the current study were not exhaustive, reports of NTM infection cases and subsequent microbiological and workplace practice investigations showed that considerable progress has 
been made in understanding contamination mechanisms during healthcare treatment. Water used in the procedures appeared to be the infection source for 10 cases. This finding is particularly true for heart surgery after the alert issued concerning the global outbreak of $M$. chimaera endocarditis as a result of contaminated HCUs (8).

Our observations should prompt more stringent recommendations for prompt reporting of NTM infections and provision of clinical and environmental samples for analysis of strains. Better application of these recommendations should improve methods to identify causes of NTM infections and enable their prevention.

\section{Acknowledgments}

We thank Sylvain Dagat, Claire Daurel, Marion Duprilot, Pierre Frange, Emmanuelle Gallois, Hélène Guet-Revillet, Frédéric Janvier, Julien Jaubert, Philippe Lanotte, Ludovic Lemée, Alix Pantel, Olivia Peuchant, Catherine Simac, Soumaya Skalli, and Céline Vauterin for their contributions to this study, especially for gathering clinical and biological data; Christine Bisilliat-Gardet, Véronique Charlier, Marie-Emmanuelle Hemet, Isabelle Lacrampe, Patricia Lawson-Body, Marilyne Lemaire, Fabienne Meunier, Marie Monjean, Sylvie Tenza, Odile Vissouarn, and our collaborators Gauthier Pean de Ponfilly and Hervé Jacquier, and all other members of the Lariboisière Bacteriology Laboratory for providing expert technical assistance; and Karine Astruc, Catherine Avril, Karine Blanckaert, France Borgey, Michel Brousse, Jean-Christophe Delaroziere, Nathalie Floret-Bassissi, Jeanne-Marie Germain, Laurence Guet, Bruno Jarrige, Karima Jeblaoui, Catherine Laland, Aba Mahamat, Sophia Mechkour, Nathalie van der Mee-Marquet, Nathalie Passard, Elise Seringe, Loïc Simon, Sophie Vandesteene, lexandra Aubry, Isabelle Bonnet, Vincent Jarlier, Florence Morel, Wladimir Sougakov and Nicolas Veziris for providing support.

This study was supported by the annual grant from French Public Health Agency and the Associate Laboratory of the National Reference Center for Mycobacteria and Antimycobacterial Resistance.

\section{About the Author}

Dr. Daniau is an epidemiologic project manager in Infectious Diseases Department of Santé Publique France, Saint-Maurice, France. His primary research interest is coordination at the national level of Point Prevalence Surveys of healthcare-associated infections and antimicrobial drug use in acute care hospitals and long-term care facilities with the European Centre for Disease Prevention and Control.

\section{References}

1. Le Dantec C, Duguet JP, Montiel A, Dumoutier N, Dubrou S, Vincent V. Occurrence of mycobacteria in water treatment lines and in water distribution systems. Appl Environ Microbiol. 2002;68:5318-25. https:/ / doi.org/ 10.1128/AEM.68.11.5318-5325.2002

2. Falkinham JO III. Environmental sources of nontuberculous mycobacteria. Clin Chest Med. 2015;36:35-41. https:/ / doi.org/ 10.1016/j.ccm.2014.10.003

3. Meyers H, Brown-Elliott BA, Moore D, Curry J, Truong C, Zhang Y, et al. An outbreak of Mycobacterium chelonae infection following liposuction. Clin Infect Dis. 2002;34:15007. https:// doi.org/10.1086/340399

4. Conaglen PD, Laurenson IF, Sergeant A, Thorn SN, Rayner A, Stevenson J. Systematic review of tattoo-associated skin infection with rapidly growing mycobacteria and public health investigation of a cluster in Scotland, 2010. Euro Surveill. 2013;18:20553. https:/ / doi.org/10.2807/1560-7917. ES2013.18.32.20553

5. Carbonne A, Brossier F, Arnaud I, Bougmiza I, Caumes E, Meningaud JP, et al. Outbreak of nontuberculous mycobacterial subcutaneous infections related to multiple mesotherapy injections. J Clin Microbiol. 2009;47:1961-4. https:/ / doi.org/10.1128/JCM.00196-09

6. Leão SC, Viana-Niero C, Matsumoto CK, Lima KV, Lopes ML, Palaci M, et al. Epidemic of surgical-site infections by a single clone of rapidly growing mycobacteria in Brazil. Future Microbiol. 2010;5:971-80. https:/ / doi.org/10.2217/ fmb.10.49

7. Mora AD, Giraldo S, Castillo DA, Ferro BE. Clinical behavior of infection and disease caused by non-tuberculous mycobacteria in Latin America: scoping review [in Spanish]. Rev Peru Med Exp Salud Publica. 2021;38:318-25. https:/ / doi.org/10.17843/rpmesp.2021.382.6108

8. van Ingen J, Kohl TA, Kranzer K, Hasse B, Keller PM, Katarzyna Szafrańska A, et al. Global outbreak of severe Mycobacterium chimaera disease after cardiac surgery: a molecular epidemiological study. Lancet Infect Dis. 2017; 17:1033-41. https:/ / doi.org/10.1016/S1473-3099 (17)30324-9

9. Astagneau P, Desplaces N, Vincent V, Chicheportiche V, Botherel A, Maugat S, et al. Mycobacterium xenopi spinal infections after discovertebral surgery: investigation and screening of a large outbreak. Lancet. 2001;358:747-51. https:/ / doi.org/10.1016/S0140-6736(01)05843-3

10. Ferry C, Saussine A, Bouaziz JD, Xhaard A, Peffault de Latour R, Ribaud P, et al. Disseminated cutaneous infection due to Mycobacterium chelonae following hematopoietic stem cell transplantation. IDCases. 2014;1:68-9. https:// doi.org/10.1016/j.idcr.2014.07.002

11. Yuan SM. Mycobacterial endocarditis: a comprehensive review. Rev Bras Cir Cardiovasc. 2015;30:93-103.

12. Couderc C, Carbonne A, Thiolet JM, Brossier F, Savey A, Bernet C, et al. Non-tuberculous mycobacterial infections related to esthetic care in France, 2001-2010 [in French]. Med Mal Infect. 2011;41:379-83. https:/ / doi.org/10.1016/ j.medmal.2011.02.007

13. Ministry of Social Affairs and Health. Decree no. 2017-129 of February 3, 2017 relating to the prevention of healthcareassociated infections, 2017 [in French] [cited 2021 Dec 9]. https://www.legifrance.gouv.fr/jorf/id/ JORFTEXT000033982071

14. Rajendran P, Padmapriyadarsini C, Mondal R. Nontuberculous mycobacterium: an emerging pathogen: Indian perspective. Int J Mycobacteriol. 2021;10:217-27.

15. European Center for Disease Prevention and Control. Rapid risk assessment: invasive cardiovascular infection by 
Mycobacterium chimaera potentially associated with heatercooler units used during cardiac surgery, April 30, 2015 [cited 2021 Jun 28]. https:/ / ecdc.europa.eu/en/publicationsdata/invasive-cardiovascular-infection-mycobacteriumchimaera-potentially-associated

16. Henkle E, Hedberg K, Schafer SD, Winthrop KL. Surveillance of extrapulmonary nontuberculous mycobacteria infections, Oregon, USA, 2007-2012. Emerg Infect Dis. 2017;23:1627-30. https:// doi.org/10.3201/eid2310.170845

17. Blanc P, Dutronc H, Peuchant O, Dauchy FA, Cazanave C, Neau D, et al. Nontuberculous mycobacterial infections in a French hospital: a 12-year retrospective study. PLoS One. 2016;11:e0168290. https://doi.org/10.1371/journal. pone. 0168290

18. Jaubert J, Mougari F, Picot S, Boukerrou M, Barau G, Ali Ahmed SA, et al. A case of postoperative breast infection by Mycobacterium fortuitum associated with the hospital water supply. Am J Infect Control. 2015;43:406-8. https://doi.org/10.1016/j.ajic.2014.12.023

19. Regnier S, Cambau E, Meningaud JP, Guihot A, Deforges L, Carbonne A, et al. Clinical management of rapidly growing mycobacterial cutaneous infections in patients after mesotherapy. Clin Infect Dis. 2009;49:1358-64. https:/ /doi.org/ $10.1086 / 606050$

20. Donohue MJ, Mistry JH, Donohue JM, O'Connell K, King D, Byran J, et al. Increased frequency of nontuberculous mycobacteria detection at potable water taps within the United States. Environ Sci Technol. 2015;49:6127-33. https://doi.org/10.1021/acs.est.5b00496

21. Li T, Abebe LS, Cronk R, Bartram J. A systematic review of waterborne infections from nontuberculous mycobacteria in health care facility water systems. Int J Hyg Environ Health. 2017;220:611-20. https:// doi.org/10.1016/j.ijheh.2016.12.002

22. Regnier S, Caumes E. Non-tuberculous mycobacterial infections related to esthetic care in France, 2001-2010 [in French]. Med Mal Infect. 2011;41:667-8. https://doi.org/10.1016/j. medmal.2011.09.009

Address for correspondence: Côme Daniau, Unité Infections Associées aux Soins et Résistance aux Antibiotiques, Direction de Maladies Infectieuses, Santé Publique France, 12 Rue du Val d'Osne, 94410 Saint-Maurice, France; email: come.daniau@santepubliquefrance.fr

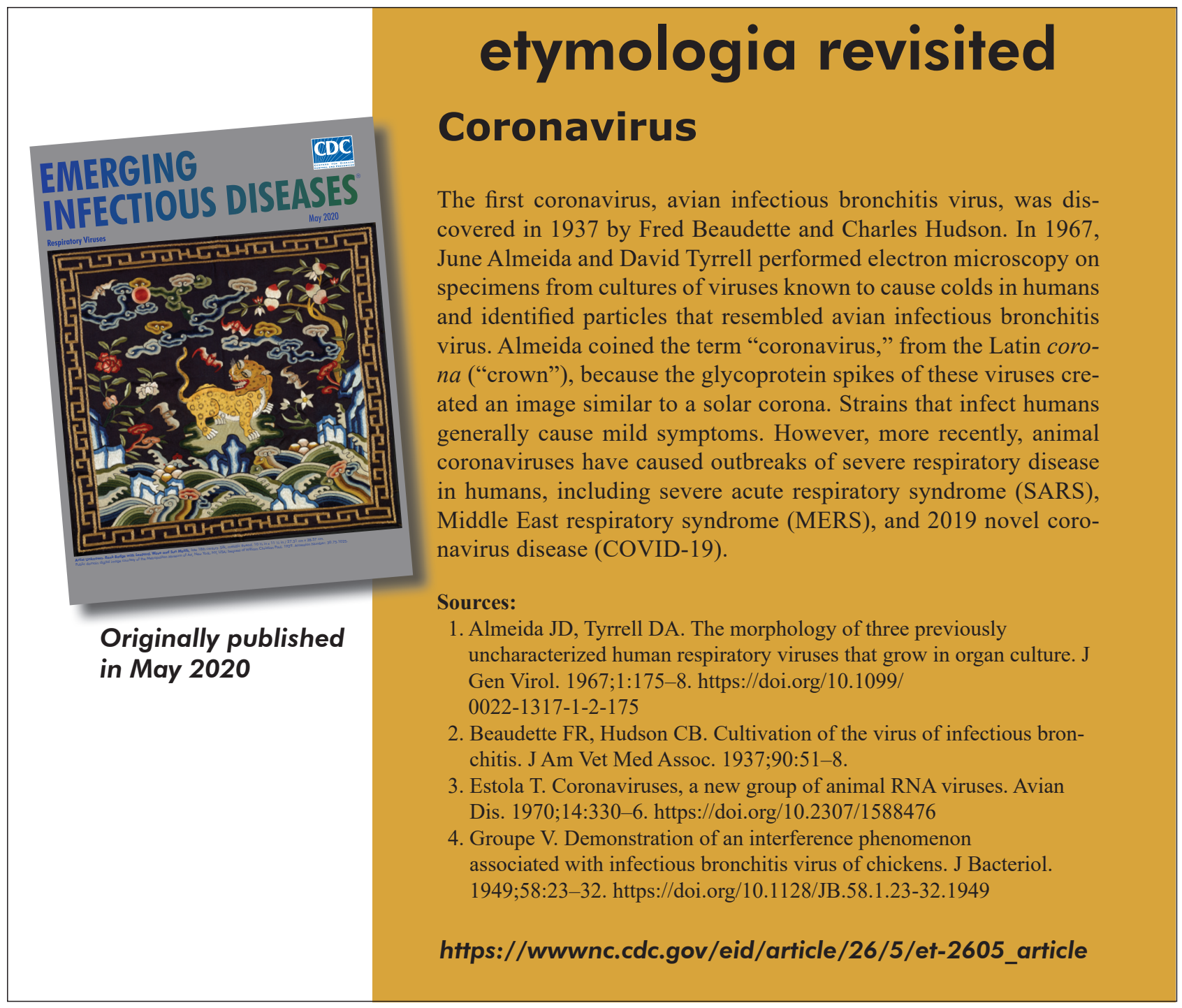

